начерковими. По-друге, щоб студенти виконували навчальні завдання необхідно: 1) вміти чути «замовника освітніх послуг» (студенти теж мають право голосу); 2) запитувати прямо - які завдання їм би хотілося виконувати (що далі векторує дії викладача для «оформлення» навчального завдання у будь-який «прийнятний для усіх формат»); 3) пропонувати «завданнєвий вибір», тобто розробляти більше різноманітних тематичних завдань (по-перше, кожен студент усвідомлює об'єктивно свій рівень і цілком спроможний виокремити оптимальні для виконання завдання; по-друге, за світоглядними орієнтирами конкретних студентів деякі завдання $є$ неприйнятними для виконання; по-третє, відсутність «навчального налаштування» теж необхідно враховувати). Сам викладач має переорієнтуватися від наразі нерезультативної формули «Я усе сам зроблю, оскільки краще знаю!» до співпрацювальної формули - «Знаю, вмію, розумію, але краще поспостерігаю та запитаю щодо можливих змін». Відповідно, сучасний викладач філософії постає (спів)розробляльником праксису: він створює навчальну основу, але радо вносить коригування задля спільнвигодового майбутнього.

Отже, філософія не є навчальною дисципліною для «ознаннєвлювання», «навичкоформування» та «вміннєвдосконалювання» студентів вишу, вона уможливлює свідоме саморозвивання кожного задля індивідуальних та суспільних зисків усього людства, а оптимізоване семінарування може цьому посприяти.

DOI https://doi.org/10.30525/978-9934-26-114-5-36

\title{
MODERN PHILOSOPHY OF INCLUSIVE EDUCATION OF DEAF STUDENTS
}

\author{
Zamsha A. V. \\ PhD in Psychology, \\ Head of Sign Language Education Division \\ Mykola Yarmachenko Institute of Special Education and Psychology \\ of the NAES of Ukraine \\ Kyiv, Ukraine
}

The practice of implementation of inclusive philosophy in deaf education raises two important issues - the academic integration and the social integration of such children in the general education settings. 
The issue of academic integration is less controversial, as it implies that deaf students have access to educational programs that are similar in scope to the educational programs for hearing students. In this case, accommodations and modifications relate to the educational process, not the content of education.

At the same time, the issue of social integration of deaf students in inclusive education is much more complex. In this context, it is appropriate to distinguish two conceptual approaches to the organization of inclusive education of deaf students, such as social and cultural approaches [7].

The social approach considers the deaf student from the standpoint of the biopsychosocial model, which is applied to all categories of students with disabilities. Although UNESCO in 1994 in The Salamanca Statement and Framework for Action on Special Needs Education assigned deaf students to a special category of children with specific communication needs. Given the uniqueness of deaf students' communicative needs, special education can be more rational and effective than inclusive education [6].

On the basis of the social approach, the needs of deaf students are mainly associated not with communicative but with sensory needs, i.e. those that are directly related to hearing impairment, which limits student learning activity and restricts the opportunities for participation and interaction with hearing members in the educational process - students, teachers, managers, etc.

Thus, the issue of social integration of deaf students is considered solely from the standpoint of their entry into the hearing community [2]. Under these conditions, the special needs of deaf students in inclusive learning settings provide mainly through the use of technologies of hearing aids, FM systems, visibility, etc.

However, determining the special needs of deaf students only as sensory needs makes it impossible to eliminate barriers that limit the learning activities and restrict the participation of deaf students in the inclusive educational process [4]. As a result of this approach, the issue of social integration remains unresolved. A deaf student becomes not a 'participant' but a 'visitor' in the school community [5].

In order to address the issue of social integration of deaf students in inclusive education was developed cultural approach to education.

One of the fundamental provisions of this approach is to create a bimodal-bilingual educational environment as a condition for providing communication needs of deaf students. In this approach, Sign and Spoken languages are used as the means of communication in the learning process.

In this approach, the communicative needs of deaf students arise not through hearing impairment, but through the identification of such students with the deaf community as a linguistic and cultural minority. This linguistic 
and cultural minority has developed effective ways for high-quality social interaction and integration of deaf children at the same time into both communities - the deaf community and the hearing community.

This approach proposes to consider the inclusive education of deaf students not in the light of education of children with disabilities but to consider this issue through the light of minority education.

The main positions of the cultural approach to inclusive education of deaf children are defined by the World Federation of the Deaf and Committee on the Rights of Persons with Disabilities [3, 8].

In particular, the cultural approach to inclusive education of deaf students involves changes in the educational program of the classroom and subject curricula. In the educational program should be added a subject 'Sign Language and Deaf Culture'. The content of curricula on various objects should be supplemented by the topics of deaf history and culture. Adjustments are also made to curricula for the study of spoken languages, which provide for changes in the requirements for learning outcomes of deaf students as indicators of their knowledge of the spoken language, which should be limited to reading and writing, i.e. those types of spoken activities that are available to them.

The changes also apply to premises, because school should be created a space where participants speak Sign Language only.

Teachers are subject to increased language training requirements - they must be fluent in the national sign language. In addition, teachers need to know the technology of bimodal-bilingual teaching.

This approach also involves creating conditions for the social identification of deaf children with the deaf community. For this, the necessary condition is to attract adult teachers as socio-cultural and linguistic models to identify deaf children. Also important to create an accessible environment for interaction, in particular, enroll in one class a few deaf students who can interact with each other in the learning process.

Special attention requires the implementation of communication accessibility technology of the educational process for deaf students, which involves the communication assistants. Thus, the communication assistant can be both a professional sign language interpreter and a paraprofessional signing transliterator who transliterate on SEE or another specialist who knows certain communication support means such as Cued Speech, etc.

The cultural approach to inclusive education of deaf students changes the professional tasks of special teachers. In these conditions, their main task is not to remediate development, but to compensate and abilitate children with hearing impairment to optimize their development [1].

Thus, high-quality inclusive education of deaf students can be provided only if their communicative needs are met as representatives of the linguistic 
and cultural minority, which involves meeting the requirements of the cultural approach to learning, including the following: adding a national Sign Language in the educational program for class to its study by hearing and deaf students; engaging deaf teachers; organizing the Sign-Spoken educational process; recognition of the priority of studying by deaf students the writing and reading as the accessible forms of spoken language for them; mandatory enrollment more than one deaf student in one class; studying by hearing teachers' the Sign Language and the technics of its use in inclusive conditions.

\section{References:}

1. Замша А. В., Федоренко О. Ф. Шкільна освіта глухих - виклик для інклюзивної практики навчання. Pedagogical and psychological science and education: transformation and development vectors : Collective monograph. Vol. 1. Riga, Latvia : «Baltija Publishing», 2021. P. 160-180. doi.org/10.30525/978-9934-26-084-1-9

2. Alasim K.N. Participation and Interaction of Deaf and Hard-ofHearing Students in Inclusion Classroom. International Journal of Special Education. 2018. Vol.33, No.2. P. 493-506.

3. Committee on the Rights of Persons with Disabilities. General comment (2018) on equality and non-discrimination. https://www.right-toeducation.org/sites/right-to-education.org/files/resource-attachments/ CRPD_C_GC_6_2018_ENG.pdf

4. Fernandes J. K., Shultz Myers S. Inclusive Deaf Studies: Barriers and Pathways. Journal of Deaf Studies and Deaf Education. 2010. Vol. 15(1) P.17-29.

5. Snoddon K. The Social and Epistemological Violence of Inclusive Education for Deaf Learners. Canadian Journal of Disability Studies. 2020. № 9. P. 185-213.

6. UNESCO. The Salamanca Statement and Framework for Action on Special Needs Education. World Conference on Special Needs Education: Access and Quality. Salamanca, Spain, 7-10 June 1994. https://www.european-agency.org/sites/default/files/salamanca-statementand-framework.pdf

7. Wauters L.N., Knoors H. Social Integration of Deaf Children in Inclusive Settings. Journal of Deaf Studies and Deaf Education. 2008. Vol. 13(1). P. 21-36.

8. WFD Position Paper on Inclusive Education. Approved by WFD Board on 10 May 2018. https://wfdeaf.org/wp-content/uploads/2018/ 07/WFD-Position-Paper-on-Inclusive-Education-5-June-2018-FINALwithout-IS.pdf 